\title{
ACCOUNTING THE SEISMIC COMPONENT OF THE LATERAL PRESSURE OF AN HETEROGENEOUS ANISOTROPIC SOIL ON MASSIVE HYDROTECHNICAL STRUCTURES
}

\author{
Voytenko I.V., PhD., Assistant Professor, \\ voytinna@ukr.net, ORCID: 0000-0002-9239-8196 \\ Odessa State Academy of Civil Engineering and Architecture \\ 4, Didrichson str., Odessa, 65029, Ukraine
}

\begin{abstract}
Strength anisotropy is characteristic of layered soil bases and has been confirmed by numerous tests. The relevance and novelty of this research is to study the effect of the seismic factor on the active pressure of the friable soil medium having strength anisotropy.

A numerical experiment was carried out using a specially developed computer program, the algorithm of which used the method for determining the lateral pressure of a heterogeneous anisotropic soil, taking into account the seismic effect. The proposed method is based on the solutions of the classical theory of Coulomb, the seismic component is taken into account on the basis of the static theory of the earthquake stability of structures.

We considered a vertically ideally smooth wall in contact with a two-layer incoherent soil medium, the anisotropy of the strength properties of which is represented by hodographs of friction angle. The layers are parallel, no surface load.

A numerical research was to determine the parameters of the active pressure of the soil of the lower layer during rotation of the hodograph of friction angle with steps of $30^{\circ}$.

We used 4 hodographs: 1) $\varphi_{1}=15^{0}-20^{0}$; 2) $\varphi_{2}=20^{0}-25^{0}$; 3) $\varphi_{3}=25^{0}-30^{0}$; 4) $\varphi_{4}=30^{0}-35^{0}$ with a horizontal plane of isotropy. Seismic impact was taken into account by the seismicity coefficient, taken equal to depending on the scale 0.025 (7), 0.05 (8), 0.1 (9). The horizontal orientation of the seismic force and with an angle of $20^{\circ}$ to the horizontal plane was set.

The obtained results make it possible to evaluate the seismic effect on the lateral pressure of anisotropic soil by comparing it with the corresponding indicators obtained earlier without taking into account the seismic factor. An analysis of computer solutions indicates the increase of the active pressure in seismic conditions by $14 \%-45 \%$ compared with the same indicator, which was determined without taking into account the seismic factor.
\end{abstract}

Keywords: active pressure, strength anisotropy, seismicity, hodographs of strength characteristics.

Introduction Gravitational-type marine hydrotechnical structures and bollards, which perceive the pressure of the contact soil medium, make up about $40 \%$ of the berthing front operated in the ports of the Black Sea-Azov basin, and this figure is much higher in transport ports, which makes the diagnostic methods for calculating of such structures relevant.

The high cost of port facilities makes it necessary to search for reserves in determining the main loads. Experience shows that taking anisotropy into account when determining lateral soil pressure on retaining walls can reduce the cost of load-bearing elements by 15 percent or more.

Due to the growth trend of destructive earthquakes, it is important to take into account the seismic load when determining the lateral pressure of the soil on the retaining walls of hydrotechnical structures. It should be noted the lack of a regulatory framework governing the design of retaining structures in an anisotropic soil environment, taking into account the effects of seismic waves.

Analysis of recent research and publications. The anisotropy of soil media in contact with the rear faces of spacer structures is confirmed by numerous domestic and foreign experimental studies [1-4]. The manifestation of anisotropy is associated with the heterogeneity of layered soil bases and the peculiarities of the laying of soil particles when washing artificial fillings. 
In the work [5], the results of computer simulation of the interaction of a loose soil anisotropic medium with a retaining wall under various modes of its motion are presented. The author compares the value of the passive pressure coefficient of anisotropic sandy soil of various densities with similar results for isotropic filling. The inclusion of anisotropy led to a significant decrease in the lateral pressure coefficient in comparison with the isotropic variant.

The authors of the work [6] proposed dependences for determining the active pressure of a water-saturated loose soil on fences during the passage of a longitudinal seismic wave, taking into account inertia (during compression), changes in the internal state of the medium (during compression), and the attached mass of water.

The seismic stability analysis of a sea dam is considered in the work [7] taking into account the seismic active soil pressure, seismic inertial force, wave, hydrostatic and hydrodynamic pressures from the perspective of the modified pseudo dynamic method. Dependencies are proposed for the coefficient of stability during shear and tipping.

Earlier, numerical studies of anisotropy indices for an inhomogeneous soil interacting with a smooth retaining wall [8], demonstrating the significant effect of strength anisotropy on the active soil pressure were performed. The experiments were carried out without taking into account the seismic factor. Thus, previous studies of lateral pressure of the soil medium on retaining walls were carried out on the basis of a technique that ignores either strength anisotropy or seismic impact.

Objectives and tasks. The aim of the study was to elucidate the influence of the seismic factor on the value of the active pressure of an inhomogeneous anisotropic soil. To achieve this goal, a numerical study of the lateral pressure indices of anisotropic soil at different seismicity were carried out, followed by a comparison of the results with the corresponding indicators that were previously determined without taking into account seismic effects.

Research methodology. The building codes that govern the construction in seismic regions of Ukraine [9], it is recommended to calculate the hydrotechnical structures for the action of seismic forces in two ways:

1) by the direct dynamic method, in which the seismic force is displayed as a set of records of the seismic motion of the base as a function of time;

2) the linear spectral method, in which the materials of the structure and foundation are considered linearly elastic.

When designing massive retaining walls, due to their stiffness, the dynamic coefficient is taken to be unity, since the frequency of natural and forced vibrations of structures of this structural type coincide.

Previously, a technique was developed to determine the lateral pressure of a multilayer anisotropic soil on the retaining walls of hydrotechnical structures taking into account seismic effects [10]. The conclusions were based on the main points of the classical theory of C. Coulomb, the use of which for active pressure gives insignificant errors within 2-3\%. The approximate Coulomb method is recommended for complex cases of interaction between port facilities and the soil environment.

The seismic impact is taken into account within the framework of the static theory of earthquake resistance of structures, which is justified and recommended for similar problems for isotropic soil due to the poor development of the provisions of the dynamic theory in engineering practice.

To analyze the effect of seismic forces on the lateral pressure of a heterogeneous anisotropic soil, a numerical experiment was carried out using a specially developed computer program.

As an example, we considered a vertically ideally smooth wall interacting with a two-layer soil environment, the hodographs of the strength characteristics of which were assumed identical. In basic calculations, the orientation of the layers is parallel and horizontal, there is no surface load. Calculations were carried out for loose soils. Cases of horizontal orientation of the seismic force and its location at an angle of 200 to the horizontal plane with the estimated seismicity of 7,8 and 9 points were considered.

Hodographs of the angle of internal friction and adhesion, satisfying condition (1), are given in the form of piecewise linear graphs (Fig. 1).

$$
\varphi_{n}(\beta)=\varphi_{n}(\beta+\pi) ; \quad c_{n}(\beta)=c_{n}(\beta+\pi) .
$$


a)

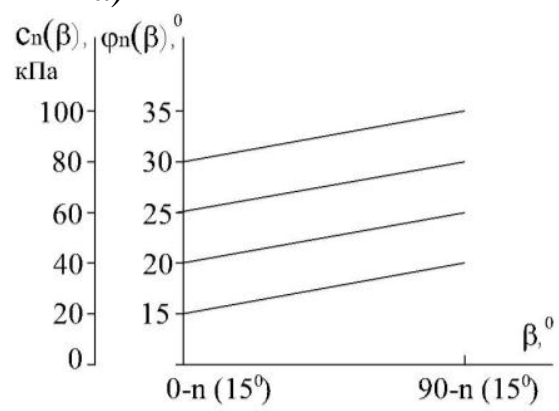

b)

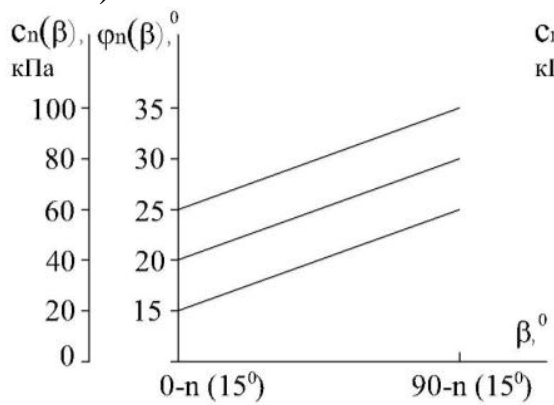

c)

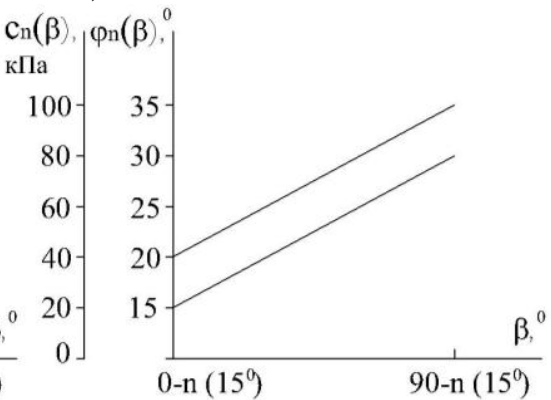

Fig. 1. Piecewise linear hodographs of the angle of internal friction and soil adhesion, adopted in a numerical study:

$\mathrm{a}-\Delta \mathrm{c}_{\mathrm{n}}(\beta)=20 \kappa \mathrm{Pa}, \Delta \varphi_{\mathrm{n}}(\beta)=5^{0} ; \mathrm{b}-\Delta \mathrm{c}_{\mathrm{n}}(\beta)=40 \kappa \mathrm{Pa}, \Delta \varphi_{\mathrm{n}}(\beta)=10^{0} ; \mathrm{c}-\Delta \mathrm{c}_{\mathrm{n}}(\beta)=60 \kappa \mathrm{Pa}, \Delta \varphi_{\mathrm{n}}(\beta)=15^{0} ;$ $\mathrm{n}$ is an integer variable; $\Delta$ is the difference between the maximum and minimum parameters of the hodograph

The active pressure of the lower layer for loose soil $(c=0)$ and in the absence of surface load $(\mathrm{q}=0)$ is determined by the formula $(2)$ :

$$
E_{a, 2}=\gamma_{2} h_{2}^{2} N_{\gamma, 2}\left(1+N_{c o r, 2}\right),
$$

where $N_{\gamma, 2}, N_{c o r, 2}$ are coefficients obtained respectively from the dependencies (3) and (4):

$$
\begin{gathered}
N_{\gamma, 2}=\frac{1}{2} \frac{\sin \left(\beta_{3}-\beta_{1,1}\right) \sin \left(\beta_{3}-\beta_{2,2}\right) \sin \left(\varphi_{2}\left(\beta_{2,2}\right)-\beta_{2,2}-\omega_{\gamma, 2}\right)}{\sin ^{2} \beta_{3} \sin \left(\beta_{2,2}-\beta_{1,1}\right) \sin \left(\beta_{3}-\beta_{2,2}+\varphi_{2}\left(\beta_{2,2}\right)+\delta_{2}\left(\beta_{3}\right)\right)} ; \\
N_{c o r, 2}=\frac{\sin \left(\beta_{3}-\beta_{2,2}\right) \sin \left(\beta_{1,2}-\beta_{1,1}\right)}{\sin \left(\beta_{3}-\beta_{1,1}\right) \sin \left(\beta_{2,2}-\beta_{1,2}\right)} .
\end{gathered}
$$

where $\beta_{3}-$ wall orientation angle;

$\beta_{1,1}-$ angle of orientation of the surface of the backfill or soil base;

$\beta_{1,2}$ - angle of orientation of the surface of the lower layer;

$\beta_{2,2}$ - the angle of the surface of the collapse of the lower layer;

$\delta_{2}\left(\beta_{3}\right)$ - oughness angle (ground friction on the wall material);

$\omega_{\gamma, 2}-$ seismic angle for bulk forces relative to their direction of action, determined from (5):

$$
\omega_{\gamma, 2}=\operatorname{arctg}\left[\left(\alpha \frac{\gamma_{\text {sat }, 2}}{\gamma_{\text {sus }, 2}} \cos \chi\right) /\left(1-\frac{\gamma_{\text {sat }, 2}}{\gamma_{\text {sus }, 2}} \alpha \sin \chi\right)\right],
$$

where $\gamma_{s a t, 2}, \gamma_{\text {sus }, 2}$ - the specific gravity of the soil of the lower layer, respectively, in saturated and suspended state;

$\alpha$ - seismicity coefficient, which is a product of coefficients that take into account the functional responsibility of the structure and the seismicity of the construction area by the dynamic coefficient, depending on the category of soil and the period of natural oscillations of the system [9];

$\chi$ - angle of inclination of seismic force to the horizon;

$\gamma_{2}$ - specific gravity of the bottom layer saturated with water determined by the formula (6):

$$
\gamma_{2}=\gamma_{\text {в38,2 }}\left(1-\frac{\gamma_{\text {sat }, 2}}{\gamma_{\text {sus }, 2}} \alpha \sin \chi\right) / \cos \omega_{\gamma, 2} .
$$

$h_{2}-$ the power of the lower layer on the vertical projection of the wall.

Based on the results of previous studies of the pressure of an inhomogeneous anisotropic soil on the retaining wall, the author conducted a numerical experiment in which the active pressure of the lower layer was determined during rotation of the hodographs of the angle of internal friction when the layered plane was oriented relative to the horizontal from 00 to $180^{\circ}$ with a step of $30^{\circ}$.

The pressure of the lower layer was determined for various variants of strength anisotropy with characteristic hodographs of the angle of internal friction: 1) $\left.\varphi_{1}=15^{0}-20^{0} ; 2\right) \varphi_{2}=20^{0}-25^{0}$; 3) $\varphi_{3}=25^{0}-30^{0}$; 4) $\varphi_{4}=30^{0}-35^{\circ}$ with a horizontal plane of isotropy. 
The seismic impact was taken into account by the seismic coefficient $\alpha$, which was taken equal to the earthquake magnitude equal to 0.025 ( 7 points); 0.05 ( 8 points); 0.1 ( 9 points).

As a result of the calculation, the following indicators were determined:

- coefficient $\mathrm{N}_{\gamma, 2}$, characterizing the influence of the self-weight of the soil medium within the prism of the collapse;

- component of the active pressure of the lower layer $\mathrm{E}_{\mathrm{a}, 2}$;

- angle of orientation of the sliding surface $\beta_{2,2}$, corresponding to extreme pressure.

- the anisotropy coefficient of the lower layer, determined by the formula (7):

$$
k_{a, 2}=\frac{E_{a, 2} \text { (anis.) }}{E_{a, 2} \text { (is.) }}
$$

where $E_{a, 2}$ (anis.) - active soil pressure of the lower layer, determined taking into account the strength anisotropy;

$E_{a, 2}$ (is.) - active soil pressure of the lower layer, determined in an isotropic soil environment at $\varphi_{2}=\varphi_{2, \min }=$ const, $\mathrm{c}_{2}=\mathrm{c}_{2, \min }=$ const.

The results of the study. The results of the numerical study are presented in tabular and graphical form. Tables 1-4 present the results of calculations of the parameters of active pressure for the minimum and maximum indicators of soil strength and the corresponding seismicity. With an inclined orientation of the seismic force, lower values are obtained in comparison with the corresponding values for the horizontal component of the seismic.

Table 1 - Parameters $\mathrm{N}_{\gamma, 2}, \mathrm{E}_{\mathrm{a}, 2}, \beta_{2,2}, \mathrm{k}_{\mathrm{a}, \mathrm{x}, 2}$ depending on orientation layering planes $\varpi$ relative to horizontal for given hodographs of the angle of internal friction of the lower layer $\varphi=15^{0}-20^{0}, \chi=0, \alpha=0.025$

\begin{tabular}{|c|c|c|c|c|}
\hline$\varpi$ & $\mathrm{N}_{\gamma, 2}$ & $\mathrm{E}_{\mathrm{a}, 2}$ & $\beta_{2,2}$ & $\mathrm{k}_{\mathrm{a}, \mathrm{x}, 2}$ \\
\hline 0 & 0.2748347 & 14.02387 & 230 & 0.9034714 \\
\hline 30 & 0.2924811 & 14.92431 & 228 & 0.9614810 \\
\hline 60 & 0.2996764 & 15.29146 & 234 & 0.9851342 \\
\hline 90 & 0.2827424 & 14.42737 & 235 & 0.9294665 \\
\hline 120 & 0.2666833 & 13.60793 & 235 & 0.8766750 \\
\hline 150 & 0.2581598 & 13.17301 & 231 & 0.8486556 \\
\hline 180 & 0.2748347 & 14.02387 & 230 & 0.9034714 \\
\hline \multicolumn{5}{|c|}{$\varphi=$ const $=15^{0}$} \\
\hline 231 & 0.3041986 & 15.52221 & 231 & 1 \\
\hline
\end{tabular}

Table 2 - Parameters $\mathrm{N}_{\gamma, 2}, \mathrm{E}_{\mathrm{a}, 2}, \beta_{2,2}, \mathrm{k}_{\mathrm{a}, \mathrm{x}, 2}$ depending on orientation layering planes $\varpi$ relative to horizontal for given hodographs of the angle of internal friction of the lower layer $\varphi=15^{0}-20^{0}, \chi=0, \alpha=0.1$

\begin{tabular}{|c|c|c|c|c|}
\hline$\varpi$ & $\mathrm{N}_{\gamma, 2}$ & $\mathrm{E}_{\mathrm{a}, 2}$ & $\beta_{2,2}$ & $\mathrm{k}_{\mathrm{a}, \mathrm{x}, 2}$ \\
\hline 0 & 0.3091011 & 15.89546 & 223 & 0.9169496 \\
\hline 30 & 0.3288590 & 16.91150 & 221 & 0.9755614 \\
\hline 60 & 0.3283551 & 16.88559 & 228 & 0.9740664 \\
\hline 90 & 0.3105893 & 15.97199 & 229 & 0.9213644 \\
\hline 120 & 0.2936898 & 15.10293 & 230 & 0.8712317 \\
\hline 150 & 0.2906190 & 14.94502 & 225 & 0.8621222 \\
\hline 180 & 0.3091011 & 15.89546 & 223 & 0.9169496 \\
\hline \multicolumn{5}{|l|}{$\varphi=$ const $=15^{0}$} \\
\hline 224 & 0.3370972 & 17.33515 & 224 & 1 \\
\hline
\end{tabular}


Table 3 - Parameters $\mathrm{N}_{\gamma, 2}, \mathrm{E}_{\mathrm{a}, 2}, \beta_{2,2}, \mathrm{k}_{\mathrm{a}, \mathrm{x}, 2}$ depending on orientation layering planes $\varpi$ relative to horizontal for given hodographs of the angle of internal friction

of the lower layer $\varphi=30^{0}-35^{0}, \chi=0, \alpha=0.025$

\begin{tabular}{|c|c|c|c|c|}
\hline$\varpi$ & $\mathbf{N}_{\gamma, 2}$ & $\mathrm{E}_{\mathrm{a}, 2}$ & $\beta_{2,2}$ & $\mathrm{k}_{\mathrm{a}, \mathrm{x}, 2}$ \\
\hline 0 & 0.1521941 & 7.765941 & 239 & 0.8747408 \\
\hline 30 & 0.1631560 & 8.325292 & 238 & 0.9377449 \\
\hline 60 & 0.1738292 & 8.869907 & 240 & 0.9990894 \\
\hline 90 & 0.1629757 & 8.316089 & 241 & 0.9367083 \\
\hline 120 & 0.1526193 & 7.787639 & 242 & 0.8771847 \\
\hline 150 & 0.1427363 & 7.283342 & 243 & 0.8203817 \\
\hline 180 & 0.1521941 & 7.765941 & 239 & 0.8747408 \\
\hline \multicolumn{5}{|c|}{$\varphi=$ const $=30^{\circ}$} \\
\hline 239 & 0.1739877 & 8.877992 & 239 & 1 \\
\hline
\end{tabular}

Table 4 - Parameters $\mathrm{N}_{\gamma, 2}, \mathrm{E}_{\mathrm{a}, 2}, \beta_{2,2}, \mathrm{k}_{\mathrm{a}, \mathrm{x}, 2}$ depending on orientation layering planes $\varpi$ relative to horizontal for given hodographs of the angle of internal friction of the lower layer $\varphi=30^{0}-35^{0}, \chi=0, \alpha=0.1$

\begin{tabular}{|c|c|c|c|c|}
\hline$\varpi$ & $\mathrm{N}_{\gamma, 2}$ & $\mathrm{E}_{\mathrm{a}, 2}$ & $\beta_{2,2}$ & $\mathrm{k}_{\mathrm{a}, \mathrm{x}, 2}$ \\
\hline 0 & 0.1752361 & 9.011479 & 236 & 0.8882496 \\
\hline 30 & 0.1871146 & 9.622327 & 235 & 0.9484600 \\
\hline 60 & 0.1957509 & 10.06645 & 237 & 0.9922367 \\
\hline 90 & 0.1842122 & 9.473072 & 238 & 0.9337482 \\
\hline 120 & 0.1731929 & 8.906410 & 239 & 0.8778931 \\
\hline 150 & 0.1639416 & 8.430662 & 237 & 0.8309993 \\
\hline 180 & 0.1752361 & 9.011479 & 236 & 0.8882496 \\
\hline \multicolumn{5}{|l|}{$\varphi=$ const $=30^{0}$} \\
\hline 235 & 0.1972825 & 10.14521 & 235 & 1 \\
\hline
\end{tabular}

For comparative analysis, test results are presented in the form of graphs of the coefficient $\mathrm{N}_{\gamma, 2}$ (Fig. 2) and ultimate pressure $\mathrm{E}_{\mathrm{a}, 2}$ (Fig. 3) depending on the orientation of the layered plane for various travel time curves of the angle of internal friction. For clarity, graphs with seismicity of 7 points are shown. $(\alpha=0.025), 9$ points $(\alpha=0.1)$ and obtained in previous calculations excluding seismic effects $(\alpha=0)$.

An analysis of the results made it possible to establish the effect of the seismic component on the value of the active pressure of the soil, which has strength anisotropy:

1. The maximum pressures were obtained with a horizontal directivity of the seismic force and, logically, with maximum divinity.

2. With an increase in soil strength, active pressure, taking into account seismic effects, decreases.

3. Comparison with previous anisotropic pressure data excluding seismic effects showed an increase in active pressure taking into account the seismic factor by $14 \%-45 \%$ in directions, and this percentage also increases with an increase in strength indicators.

4. Comparison of isotropic pressures with minimum strength parameters of hodographs shows a slight increase in active pressure taking into account seismic by 1.04-1.19 times with a corresponding increase in soil strength and the calculated measure of earthquake intensity.

5. The anisotropy coefficients, which are the ratio of the anisotropic active pressure to the corresponding isotropic index, decrease with increasing seismicity and increase with increasing strength.

Thus, taking seismic effects into account significantly affects the lateral pressure of an inhomogeneous anisotropic soil, which must be taken into account when designing earthquakeresistant hydrotechnical structures. 


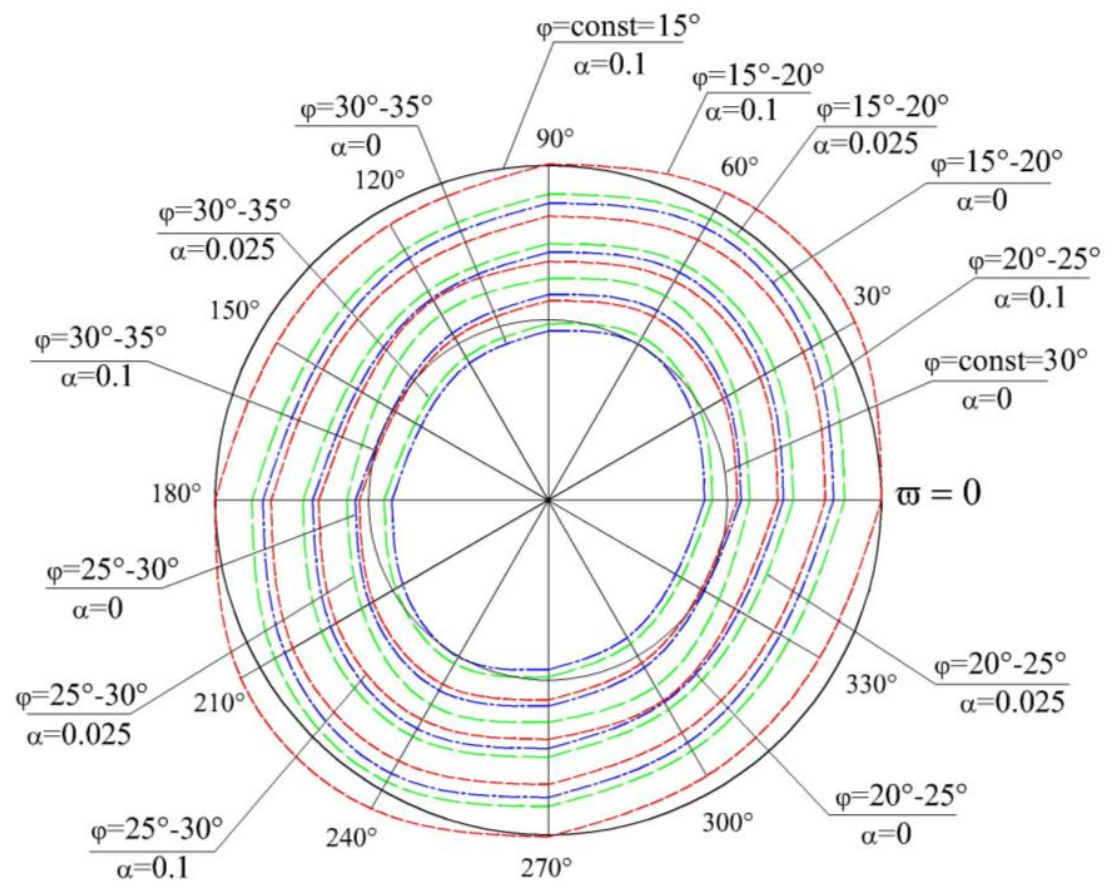

Fig. 2. Graphs of the coefficient of dependency $\mathrm{N}_{\gamma, 2}$ on orientation layering planes of hodographs of the lower layer $\varpi$ for given hodographs angle of internal friction of the lower layer $\varphi$ and seismicity coefficient $\alpha$

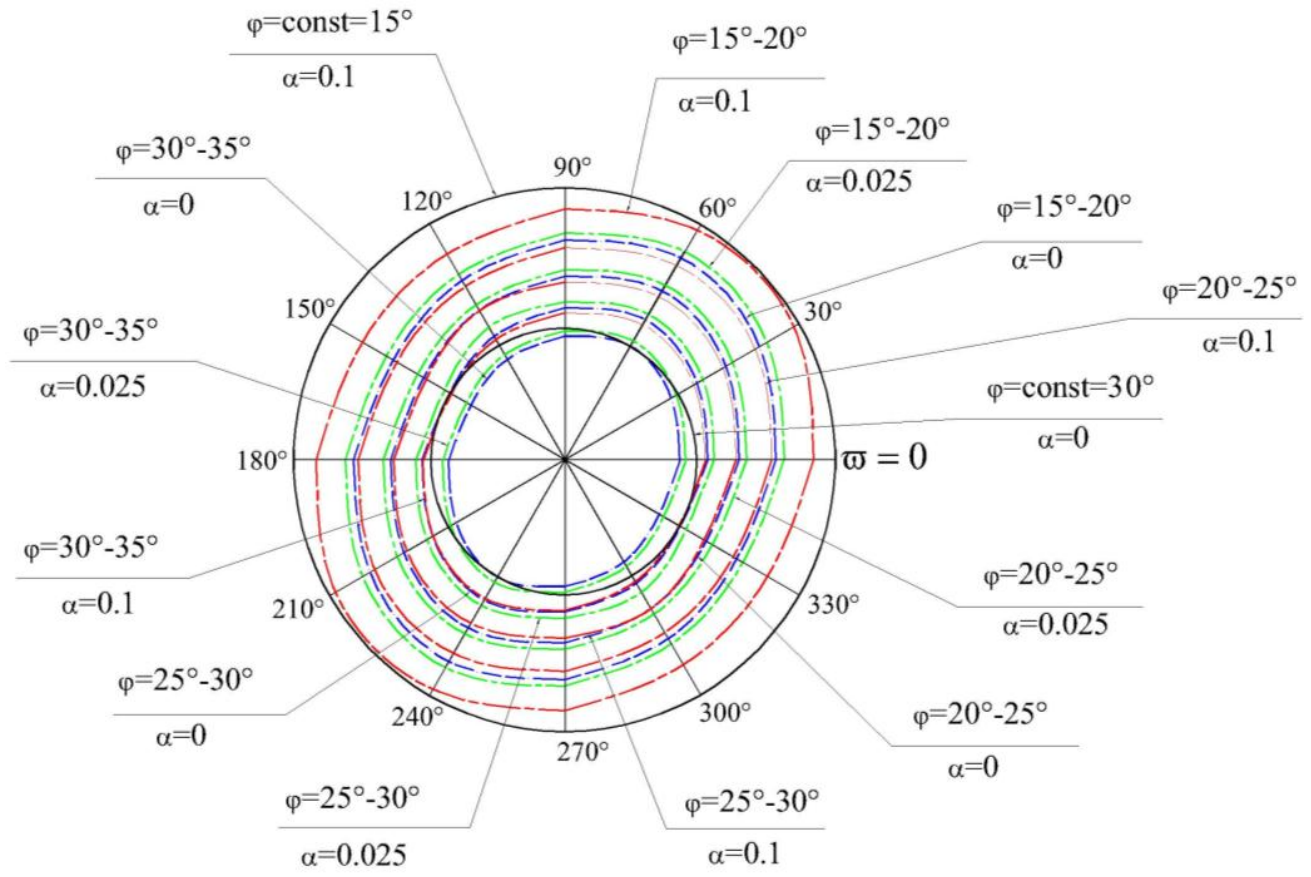

Fig. 3. Pressure dependency graphs $\mathrm{E}_{\mathrm{a}, 2}$ on the orientation of the layered plane hodographs of the lower layer $\varpi$ for given hodographs of the angle of the inner lower layer pressure $\varphi$ and seismic coefficient $\alpha$

Conclusion. Thus, for the first time, a numerical study of the effect of seismic effects on the lateral pressure of an inhomogeneous anisotropic granular soil was carried out. The experimental data indicate a significant effect of strength anisotropy and the seismic factor on the active pressure of the soil medium. The obtained results can be used in the development of regulatory documentation governing the design of gravity-type marine hydrotechnical structures. Prospects for further research are aimed at studying the interaction of cohesive soils with retaining walls in earthquake-prone conditions. 


\title{
References
}

[1] Z. Gao, "Efficient Approach to Characterize Strength Anisotropy in Soil", Journal of Engineering Mechanics, vol. 138, Issue 12, pp. 1447-1456, 2012.

[2] W. Ratananikom, "An investigation of anisotropic elastic parameters of Bangkok Clay from vertical and horizontal cut specimens", Geomechanics and Geoengineering: An International Journal, vol. 8, pp. 15-27, 2013.

[3] C. Zarei, H. Soltani-Jigheh, K. Badv," Effect of Inherent Anisotropy on the Behavior of Fine-Grained Cohesive Soils", Int J Civ Eng., vol. 17, pp. 687-697, 2019. https://doi.org/10.1007/s40999-018-0292-1.

[4] Matylda Tankievicz, "Experimental Investigation of Strength Anosotropy of Varved Clay", Procedia Earth and Planetary Science, vol. 15, pp. 732-737, 2015. https://doi.org/10.1016/j.proeps.2015.08.116.

[5] A.B. Muhiddin, A Study of Passive Earth Pressure in Anisotropic Sand with Various Wall Movement Mode, Old Dominion University ODU Digital Commons. Civil \& Environmental Engineering Theses \& Dissertations. 2010. [Online]. Available: https://digitalcommons.odu.edu/cgi/viewcontent.cgi?article $=1059 \&$ context=cee_etds.

[6] O.I. Mirkevich, M.N. Kruglenya, V.A. Stan'kovskaia. "Seysmicheskiye volny s aktivnoye davleniye sypuchykh gruntov na ograzhdeniya". [Online]. Available: https://docplayer.ru/71558890-Seysmicheskie-volny-i-aktivnoe-davlenie-sypuchih-gruntovna-ograzhdeniya.html.

[7] B.G. Rajesh, D. Choudhury, "Stability of seawalls using modified pseudo-dynamic method under earthquake conditions", Applied Ocean Research, vol. 65, pp. 154-165, 2017. https://doi.org/10.1016/j.apor.2017.04.004.

[8] I.V. Voytenko, "Analiz chislennogo issledovaniya pokazateley anizotropii aktivnogo davleniya neodnorodnogo grunta", Budivelni konstrukziyi, Mizhvidomchiy naukovotekhnichniy zbirnik "Mekhanika gruntov, geotekhnika ta fundamentobuduvannya", vol. 83, pp. 339-347, 2016.

[9] DBN V.1.1-12:2006. Budivnictvo u seysmichnikh rayonach Ukrayiny. K.: Minbud Ukrayiny, 2006.

[10] A.V. Shkola, I.V. Voytenko, "Uchyot anizotropii mnogosloynogo grunta pri opredeleniyi aktivnogo davleniya na podporniye steny s echyoton seysmicheskikh vozdeystviy, Visnik Odes 'koï derzhavnoï akademiï budivnictva ta arhitekturi, vol. 4, pp. 394-407, 2001.

\section{УРАХУВАННЯ СЕЙСМІЧНОЇ СКЛАДОВОЇ БІЧНОГО ТИСКУ НЕОДНОРІДНОГО АНІЗОТРОПНОГО ГРУНТУ НА МАСИВНІ ГІДРОТЕХНІЧНІ СПОРУДИ}

\author{
Войтенко I.В., к.т.Н., доцент, \\ voytinna@ukr.net, ORCID: 0000-0002-9239-8196 \\ Одеська державна академія будівниитва та архітектури \\ вул. Дідріхсона, 4, м. Одеса, 65029, Україна
}

\begin{abstract}
Анотація. Анізотропія міцності характерна для шаруватих грунтових основ i підтверджена численними випробуваннями. Актуальність і новизна даного дослідження полягає у вивченні впливу сейсмічного фактора на показники активного тиску пухкого грунтового середовища, що володіє міцнісною анізотропією.

Проведено чисельний експеримент 3 використанням спеціально розробленої комп'ютерної програми, в алгоритм якої покладено методику визначення бічного тиску неоднорідного анізотропного грунту 3 урахуванням сейсмічного впливу. Запропонована методика спирається на рішення класичної теорії Ш. Кулона, сейсмічна складова враховується на підставі статичної теорії сейсмостійкості споруд.

Розглядалася вертикальна ідеально гладка стінка, що контактує 3 двошаровим незв'язним грунтовим середовищем, анізотропія міцнісних властивостей якої представлена годографом кута внутрішнього тертя. Шари паралельні, поверхневе навантаження відсутнє.
\end{abstract}


Чисельне дослідження полягало у визначенні параметрів активного тиску грунту нижнього шару при обертанні годографа кута внутрішнього тертя з кроком $30^{0}$. Використовувалися 4 годографи: 1) $\varphi_{1}=15^{0}-20^{0}$; 2) $\varphi_{2}=20^{0}-25^{0}$; 3) $\varphi_{3}=25^{0}-30^{0}$; 4) $\varphi_{4}=30^{0}-35^{0}$ з горизонтальною площиною ізотропії. Сейсмічна дія враховувалася коефіцієнтом сейсмічності, що приймається рівним в залежності від бальності 0.025 (7 балів), 0.05 (8 балів), 0.1 (9 балів). Задавалася горизонтальна орієнтація сейсмічної сили і $з$ кутом нахилу $20^{\circ}$ до горизонтальної площини.

Отримані результати дозволяють оцінити сейсмічний вплив на бічний тиск анізотропного грунту шляхом порівняння з відповідними показниками, отриманими раніше без урахування сейсмічного фактора. Аналіз комп'ютерних рішень свідчить про збільшення результуючої активного тиску в сейсмічних умовах на $14 \%-45 \%$ в порівнянні $з$ аналогічним показником, визначення якого проводилося без урахування сейсмічного фактора.

Ключові слова: активний тиск, міцнісна анізотропія, сейсмічність, годографи характеристик міцності.

\title{
УЧЕТ СЕЙСМИЧЕСКОЙ СОСТАВЛЯЮЩЕЙ БОКОВОГО ДАВЛЕНИЯ НЕОДНОРОДНОГО АНИЗОТРОПНОГО ГРУНТА НА МАССИВНЫЕ ГИДРОТЕХНИЧЕСКИЕ СООРУЖЕНИЯ
}

\author{
Войтенко И.В., к.т.н., доцент, \\ voytinna@ukr.net, ORCID: 0000-0002-9239-8196 \\ Одесская государственная академия строительства и архитектуры \\ ул. Дидрихсона, 4, г. Одесса, 65029, Украина
}

Аннотация. Анизотропия прочности характерна для слоистых грунтовых оснований и подтверждена многочисленными испытаниями. Актуальность и новизна данного исследования заключается в изучении влияния сейсмического фактора на показатели активного давления рыхлой грунтовой среды, обладающей прочностной анизотропией.

Проведен численный эксперимент с использованием специально разработанной компьютерной программы, в алгоритм которой положена методика определения бокового давления неоднородного анизотропного грунта с учетом сейсмического воздействия. Предложенная методика опирается на решение классической теории Ш. Кулона, сейсмическая составляющая учитывается на основании статической теории сейсмостойкости сооружений.

Рассматривалась вертикальная идеально гладкая стенка, контактирующая с двухслойной несвязной грунтовой средой, анизотропия прочностных свойств которой представлена годографом угла внутреннего трения. Слои параллельны, поверхностная нагрузка отсутствует.

Численное исследование заключалось в определении параметров активного давления грунта нижнего слоя при вращении годографа угла внутреннего трения с шагом $30^{0}$. Использовались 4 годографа: 1) $\varphi_{1}=15^{0}-20^{0}$; 2) $\varphi_{2}=20^{0}-25^{0}$; 3) $\varphi_{3}=25^{0}-30^{0}$; 4) $\varphi_{4}=30^{0}-35^{0}$ c горизонтальной плоскостью изотропии. Сейсмическое воздействие учитывалось коэффициентом сейсмичности, принимаемым равным в зависимости от бальности 0.025 (7 баллов), 0.05 (8 баллов), 0.1 (9 баллов). Задавалась горизонтальная ориентация сейсмической силы и с углом наклона $20^{\circ}$ к горизонтальной плоскости.

Полученные результаты позволяют оценить сейсмическое влияние на боковое давление анизотропного грунта путем сравнения с соответствующими показателями, полученными ранее без учета сейсмического фактора. Анализ компьютерных решений свидетельствует об увеличении результирующей активного давления в сейсмических условиях на $14 \%-45 \%$ по сравнению с аналогичным показателем, определение которого проводилось без учета сейсмического фактора.

Ключевые слова: активное давление, прочностная анизотропия, сейсмичность, годографы характеристик прочности.

Стаття надійшла до редакції 24.04.2020

Bulletin of Odessa State Academy of Civil Engineering and Architecture, 2020, no. 80, page 132-139 